\title{
Hearing Loss, Tinnitus, Hyperacusis, and Diplacusis in Professional Musicians: A Systematic Review
}

\author{
Arianna Di Stadio ${ }^{1}$, Laura Dipietro ${ }^{2}$, Giampietro Ricci ${ }^{1}$, Antonio Della Volpe ${ }^{3}$, \\ Antonio Minni ${ }^{4}$, Antonio Greco ${ }^{4}$, Marco de Vincentiis ${ }^{5}$ and Massimo Ralli ${ }^{5,6, *(D)}$ \\ 1 Otolaryngology Department, University of Perugia, 06123 Perugia, Italy; \\ ariannadistadio@hotmail.com (A.D.S.); giampietro.ricci@unipg.it (G.R.) \\ 2 Highland Instruments, Cambridge, MA 02238, USA; lauradp@mit.edu \\ 3 Santobono-Pousillipon Hospital, Cochlear Implant Center, 80129 Naples, Italy; antoniodellavolpe@yahoo.it \\ 4 Department of Sense Organs, Sapienza University of Rome, 00185 Rome, Italy; \\ antonio.minni@uniroma1.it (A.M.); antonio.greco@uniroma1.it (A.G.) \\ 5 Department of Oral and Maxillo-Facial Science, Sapienza University of Rome, 00185 Rome, Italy; \\ marco.devincentiis@uniroma1.it \\ 6 Center for Hearing and Deafness, University at Buffalo, Buffalo, NY 14260, USA \\ * Correspondence: massimo.ralli@uniroma1.it; Tel.: +39-06-4997-6808
}

Received: 9 September 2018; Accepted: 24 September 2018; Published: 26 September 2018

\begin{abstract}
Professional musicians (PMs) are at high risk of developing hearing loss (HL) and other audiological symptoms such as tinnitus, hyperacusis, and diplacusis. The aim of this systematic review is to (A) assess the risk of developing HL and audiological symptoms in PMs and (B) evaluate if different music genres (Pop/Rock Music-PR; Classical Music-CL) expose PMs to different levels of risk of developing such conditions. Forty-one articles including 4618 PMs were included in the study. HL was found in 38.6\% PMs; prevalence was significantly higher among PR (63.5\%) than CL (32.8\%) PMs; HL mainly affected the high frequencies in the 3000-6000 Hz range and was symmetric in $68 \%$ PR PMs and in $44.5 \%$ CL PMs. Tinnitus was the most common audiological symptom, followed by hyperacusis and diplacusis. Tinnitus was almost equally distributed between PR and CL PMs; diplacusis was more common in CL than in PR PMs, while prevalence of hyperacusis was higher among PR PMs. Our review showed that PR musicians have a higher risk of developing HL compared to CL PMs; exposure to sounds of high frequency and intensity and absence of ear protection may justify these results. Difference in HL symmetry could be explained by the type of instruments used and consequent single-sided exposure.
\end{abstract}

Keywords: hearing loss; noise induced hearing loss; musicians; pop-rock; classic; tinnitus; hyperacusis; diplacusis

\section{Introduction}

Hearing loss (HL) can follow exposure to loud sounds; noise-induced HL is the second most common cause of HL, and accounts for about $16 \%$ of disabling HL in the adult population worldwide [1,2]. Chronic exposure to noise causes a progressive destruction of inner and outer hair cells in the cochlea following oxidative stress, metabolic exhaustion, and ischemia [3-5]. Noise-induced HL can follow work-related and recreational noise exposure [6-10] with significant impact on quality of life $[11,12]$.

Tinnitus, defined as the perception of sound without an external auditory stimulus, is a condition affecting $10-25 \%$ of the adult population, with moderate-to-severe consequences on daily activities and quality of life $[13,14]$. Risk factors for tinnitus include hearing loss, exposure to loud sounds, 
and increasing age $[15,16]$; tinnitus ranges from 35 to $77 \%$ in subjects with noise-induced HL $[17,18]$. Furthermore, subjects often report worsening of tinnitus with stress; therefore, workers subject to high work-related stress may have an increased risk of tinnitus [19,20].

Hyperacusis is defined as a reduced tolerance to sounds of average intensity, sometimes accompanied by painful sensitivity to ordinary environmental sounds, with perceptual, psychological, and social dimensions [21]. Hyperacusis is often associated tinnitus [22,23].

Diplacusis is a term used to describe an anomaly whereby the same tone is perceived as having a different pitch depending on whether it is presented in the right or in the left ear of the same listener [24,25]; evidence suggests a higher prevalence of diplacusis in individuals with hearing loss, especially asymmetric $[24,25]$.

Music, at the both entertainment and professional level, can induce HL and other audiological symptoms such as tinnitus, hyperacusis, and diplacusis [9,26]; professional musicians (PMs) are exposed to high intensity sounds for a prolonged time during the day [27]. Many studies have focused on the prevalence of HL among PMs and the degree of hearing loss among them [28-30]; however, the extent to which the musical genre affects the risk of developing hearing loss in PM remains unclear [30,31]. Different music genres such as Pop/Rock (PR) or classical (CL) music entail different levels of noise exposure, which in turn depend on several factors including the type and number of instruments that are played at the same time and the intensity of the sound that is generated [27-31].

The aims of this systematic review of the literature are to (A) assess the risk of developing HL and audiological symptoms (tinnitus, hyperacusis, diplacusis) in PMs and (B) evaluate if different music genres expose PMs to a different level of risk of developing these conditions.

\section{Materials and Methods}

\subsection{Search Strategy}

This systematic review followed the Preferred Reporting Items for Systematic Review and Meta-Analyses (PRISMA) guidelines [32]. Two researchers independently searched PubMed, Scopus, and Google Scholar (until 06/30/2018) using the following keywords: "hearing loss", "tinnitus", "hyperacusis", "music", "classical music", "rock music", "pop music", "musicians", "orchestra", "music student", "professional musician", "hearing threshold", "music exposure", and "temporary hearing loss". Both researchers independently selected and reviewed the abstracts that included a minimum of two keywords with "hearing loss" and "music" as the principal ones. The selected articles were then thoroughly read.

\subsection{Study Selection}

All publication types from 1978 to April 2018, in English, French, or Italian only, were considered for analysis, including epidemiological, case control, prospective and retrospective studies. Studies on non-PMs were excluded; a PM was defined as a person for whom playing music was the primary occupation. Articles from the same author were thoroughly checked to avoid duplicates.

\subsection{Data Extraction}

A standardised electronic data extraction form was completed with pertinent information from each article. From the articles that were selected, the following details were extracted: study design, number and age of subjects, type of music played, type of instrument played, rehearsal time, degree of hearing loss, affected frequencies, hearing loss symmetry, presence of tinnitus, hyperacusis, and diplacusis. Hearing was considered symmetrical if mean thresholds for each ear occurred within $15 \mathrm{~dB}$ of each other. 


\subsection{Data Analysis}

Meta-analyses require studies of similar comparison reporting identical outcome measures. The studies included in the present review revealed a considerable heterogeneity in study design, type of exams performed, length of observation period, and type of outcome measures. Therefore, a well-defined meta-analysis was not applicable, and a systematic review of the literature was preferred.

All data were added to a database; data related to the PR and CL genres were compared. Prevalence of symptoms was calculated as a percentage. Nominal data between PR and CL PMs, namely presence or absence of hearing loss, presence or absence of tinnitus, presence or absence of diplacusis were compared using chi-square $(\chi)$. Odds ratios were calculated for CL and PR PMs to quantify their risk of developing HL. Statistical significance level was defined at $p<0.05$.

\section{Results}

\subsection{Articles and Subjects Included in the Systematic Review}

A total of 57 articles matching the inclusion criteria were identified. Among these, nine articles were excluded because they addressed other topics $(n=2)$ or involved different populations (non-professional musicians $n=3$, singers $n=2$, music technicians $n=1$, general population $n=1$ ), and seven articles were excluded because they were centered exclusively on risk assessment without including details on specific hearing disorders. Following this selection, 41 articles were included in the review (Figure 1).

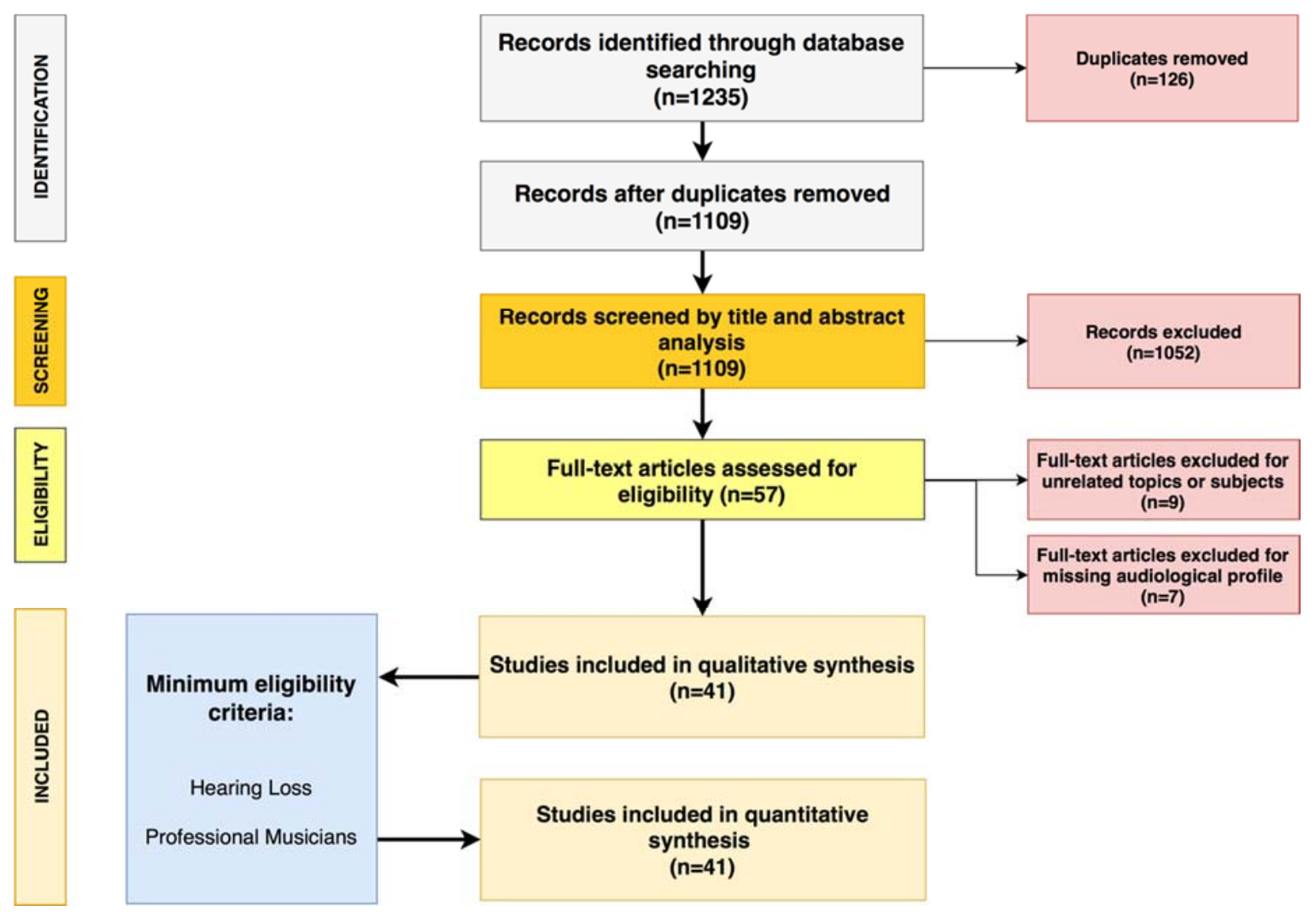

Figure 1. Preferred Reporting Items for Systematic Review and Meta-Analyses (PRISMA) diagram followed in the present review. The flow diagram depicts the flow of information through the different phases of the systematic review. It maps out the number of records identified, included and excluded, and the reasons for exclusions [32].

Details of articles included in our review are summarized in Table 1. 
Table 1. Articles included in systematic review.

\begin{tabular}{|c|c|c|c|c|c|c|c|c|c|c|c|}
\hline Author, Year & Design & Subjects $(n)$ & Age (Range) & Music Genre & Rehearsal Time (hs) & HL (\%) & HL (Frequency) & HL (Symmetry) & Tinnitus (\%) & Hyperacusis (\%) & Diplacusis (\%) \\
\hline Axelsson, 1978 [33] & PS & 83 & ns & PR & 1:00 & $30 \%$ & $3000-6000 \mathrm{~Hz}$ & Symmetric & ns & ns & ns \\
\hline Axelsson, 1981 [34] & PS & 38 & $27-33$ & PR & $4: 30$ & $28.9 \%$ & $4000-6000 \mathrm{~Hz}$ & Symmetric & ns & ns & ns \\
\hline Axelsson, 1981 [35] & PS & 139 & $20-69$ & $\mathrm{CL}$ & $\mathrm{ns}$ & $43.2 \%$ & $4000-8000 \mathrm{~Hz}$ & Symmetric & ns & ns & ns \\
\hline Karlsson, 1983 [36] & LS & 392 & $20-69$ & $\mathrm{CL}$ & ns & $25 \%$ & $6000-8000 \mathrm{~Hz}$ & Asymmetric & ns & ns & ns \\
\hline Johnson, 1986 [37] & $\mathrm{CC}$ & 60 & $24-64$ & $\mathrm{CL}$ & ns & none & ns & ns & ns & ns & ns \\
\hline Royster, 1991 [38] & PS & 59 & $30-69$ & $\mathrm{CL}$ & $2: 30$ & $52.5 \%$ & $6000 \mathrm{~Hz}$ & Asymmetric & ns & ns & ns \\
\hline Axelsson, 1995 [39] & PS & 83 & $20-46$ & PR & $3: 30$ & $10.8 \%$ & $3000-6000 \mathrm{~Hz}$ & Symmetric & $12 \%$ & $9 \%$ & ns \\
\hline Obeling, 1999 [40] & PS & 57 & $22-65$ & CL & ns & $17.5 \%$ & $4000-8000 \mathrm{~Hz}$ & Asymmetric & ns & ns & ns \\
\hline Kahari, 2001 [41] & PS & 140 & $23-64$ & $\mathrm{CL}$ & ns & $52.5 \%$ & $6000-8000 \mathrm{~Hz}$ & Asymmetric & ns & ns & ns \\
\hline Kahari, 2001 [42] & LS & 56 & $30-50$ & $\mathrm{CL}$ & ns & $76.8 \%$ & $4000-8000 \mathrm{~Hz}$ & Symmetric & ns & ns & ns \\
\hline Eaton, $2002[30]$ & PS & 53 & $25-60$ & $\mathrm{CL}$ & $3: 00$ & $24.5 \%$ & $3000-6000 \mathrm{~Hz}$ & Symmetric & ns & ns & ns \\
\hline Kahari, 2003 [43] & CSS & 139 & $26-51$ & PR & $5: 00$ & $74.1 \%$ & $3000-8000 \mathrm{~Hz}$ & Symmetric & $48 \%$ & $45 \%$ & $2.8 \%$ \\
\hline Mendes, 2007 [29] & PS & 34 & ns & PR & $\mathrm{ns}$ & $58.8 \%$ & $3000-6000 \mathrm{~Hz}$ & Symmetric & $47 \%$ & ns & $\mathrm{ns}$ \\
\hline Beltrao Amorim, 2008 [44] & PS & 30 & $18-40$ & $\mathrm{PR}$ and $\mathrm{CL}$ & $3: 50$ & $16.7 \%$ & $3000-6000 \mathrm{~Hz}$ & Symmetric & ns & ns & ns \\
\hline Sayegh, 2008 [45] & PS & 340 & $18-28$ & CL & ns & $63.8 \%$ & ns & Asymmetric & $28 \%$ & ns & ns \\
\hline Jansen, 2009 [46] & PS & 241 & $23-64$ & $\mathrm{CL}$ & ns & $51.9 \%$ & $6000 \mathrm{~Hz}$ & Symmetric & $17 \%$ & ns & $8.2 \%$ \\
\hline Hasson, 2009 [47] & CS & 250 & ns & CL & ns & $6 \%$ & ns & ns & $19 \%$ & $14 \%$ & ns \\
\hline Phillis, 2010 [48] & PS & 329 & $18-25$ & $\mathrm{PR}$ and $\mathrm{CL}$ & $2: 00$ & $45 \%$ & $4000-6000 \mathrm{~Hz}$ & Symmetric & ns & ns & ns \\
\hline Pawlaczyk, 2011 [49] & PS & 127 & $22-67$ & $\mathrm{CL}$ & $4: 30$ & $26 \%$ & $2000-4000 \mathrm{~Hz}$ & Symmetric & ns & ns & ns \\
\hline Toppila, 2011 [50] & PS & 63 & $22-52$ & $\mathrm{CL}$ & ns & $100 \%$ & $4000-6000 \mathrm{~Hz}$ & Symmetric & $9.5 \%$ & $6.3 \%$ & ns \\
\hline Samelli, 2012 [51] & CC & 16 & $21-41$ & PR & $3: 15$ & $100 \%$ & $2000-3000 \mathrm{~Hz}$ & Symmetric & ns & ns & ns \\
\hline Raymond III, 2012 [52] & PS & 32 & $35-64$ & $\mathrm{CL}$ & ns & $25 \%$ & $4000-8000 \mathrm{~Hz}$ & Symmetric & ns & ns & ns \\
\hline Patil, 2013 [53] & CC & 84 & $26-47$ & $\mathrm{CL}$ & ns & none & ns & Symmetric & $\mathrm{ns}$ & ns & ns \\
\hline Russo, 2013 [54] & PS & 44 & $41-57$ & $\mathrm{CL}$ & 4:00 & $100 \%$ & $4000-6000 \mathrm{~Hz}$ & Symmetric & ns & ns & ns \\
\hline Goncalves, 2013 [55] & CS & 50 & $21-51$ & $\mathrm{CL}$ & 4:00 & $32 \%$ & $2000-16,000 \mathrm{~Hz}$ & ns & ns & ns & ns \\
\hline Wilson, 2013 [56] & PS & 144 & $18-60$ & $\mathrm{CL}$ & 3:15 & $22.9 \%$ & $4000-8000 \mathrm{~Hz}$ & Symmetric & ns & ns & ns \\
\hline Luders, 2014 [57] & RS & 42 & $18-58$ & $\mathrm{CL}$ & ns & $7.14 \%$ & $250-3000 \mathrm{~Hz}$ & Symmetric & ns & ns & ns \\
\hline O'Brien, 2014 [58] & PS & 367 & $35-51$ & $\mathrm{CL}$ & ns & $42.5 \%$ & $2000-8000 \mathrm{~Hz}$ & $\mathrm{~ns}$ & $34 \%$ & ns & ns \\
\hline Schmidt, 2014 [59] & $\mathrm{CC}$ & 212 & $20-69$ & $\mathrm{CL}$ & 4:00 & $60.8 \%$ & $3000-6000 \mathrm{~Hz}$ & Asymmetric & ns & ns & ns \\
\hline Halevi-Katz, 2015 [31] & PS & 44 & $20-64$ & PR & 5:15 & $100 \%$ & $3000-6000 \mathrm{~Hz}$ & Symmetric & $6 \%$ & $2 \%$ & ns \\
\hline Dudarerewicz, 2015 [60] & PS & 18 & $30-58$ & CL & $3: 30$ & $27.8 \%$ & $4000 \mathrm{~Hz}$ & ns & ns & ns & ns \\
\hline Stormer, 2015 [61] & $\mathrm{CC}$ & 111 & $16-52$ & $\mathrm{PR}$ & 2:00 & $37.8 \%$ & $6000 \mathrm{~Hz}$ & Symmetric & $10 \%$ & ns & ns \\
\hline Luders, 2016 [62] & PS & 30 & $33-54$ & $\mathrm{CL}$ & $3: 00$ & $43.3 \%$ & $3000-6000 \mathrm{~Hz}$ & Symmetric & $53 \%$ & $33 \%$ & ns \\
\hline Hennir, 2016 [63] & PS & 28 & $18-25$ & CL & $2: 00$ & $25 \%$ & ns & Symmetric & ns & ns & ns \\
\hline Luders, 2016 [64] & PS & 100 & $28-38$ & $\mathrm{PR}$ and $\mathrm{CL}$ & ns & $32 \%$ & ns & ns & ns & ns & ns \\
\hline Pouryaghoub, 2017 [65] & CS & 125 & $31-38$ & $\mathrm{PR}$ and $\mathrm{CL}$ & ns & $82.4 \%$ & $3000-6000 \mathrm{~Hz}$ & Asymmetric & $51.2 \%$ & ns & ns \\
\hline Hoydal, 2017 [28] & $\mathrm{CC}$ & 111 & $16-52$ & PR & ns & $100 \%$ & $1500-6000 \mathrm{~Hz}$ & Asymmetric & $19.8 \%$ & ns & ns \\
\hline $\begin{array}{c}\text { Pawlaczyk-Luszczynska, } \\
2017 \text { [66] }\end{array}$ & $\mathrm{CC}$ & 168 & $18-29$ & $\mathrm{CL}$ & $4: 00$ & $13.1 \%$ & $6000 \mathrm{~Hz}$ & Symmetric & $32.1 \%$ & $27.4 \%$ & ns \\
\hline Stormer, 2017 [67] & CS & 111 & $22-41$ & PR & ns & ns & ns & ns & $19.8 \%$ & ns & ns \\
\hline Szibor, 2018 [68] & PS & 22 & $18-62$ & PR & ns & $95.4 \%$ & $6000 \mathrm{~Hz}$ & ns & $27.3 \%$ & $27.3 \%$ & ns \\
\hline Behar, 2018 [69] & LS & 46 & ns & $\mathrm{CL}$ & ns & $100 \%$ & $4000-8000 \mathrm{~Hz}$ & ns & ns & ns & ns \\
\hline
\end{tabular}

List of articles included in our systematic review. For each article, we specified: first author and year, type of study, number of subjects included, age range, type of music played by study participants, rehearsal time, percentage of hearing loss, affected frequencies, symmetry of hearing loss, percentage of audiological symptoms (tinnitus, hyperacusis, diplacusis). PS: prospective study; LS: longitudinal study; CS: cohort study; CC: case-control study; CSS: cross-sectional study; RS: retrospective study. PR: pop/rock; CL; classical. ns: not specified. 
Among these, 25 (60.9\%) were prospective studies, 7 (17.1\%) were case studies, $4(9.8 \%)$ were cohort studies, $3(7.4 \%)$ were longitudinal studies, 1 (2.4\%) was a cross-sectional study, and $1(2.4 \%)$ was a retrospective study. Twenty-six (63.5\%) studies were conducted on CL PMs only, 11 (26.8\%) on PR PMs only, and 4 (9.7\%) on PR and CL PMs. Thirty-two (78.1\%) studies reported details on the instruments played by the PM; in 9 studies $(21.9 \%)$ the PMs were identified as PR or CL players but details about the instruments were not provided.

The articles selected for the review included a total of 4648 PMs, 3645 CL PMs (78.4\%) and 973 PR PMs (20.9\%); 30 subjects $(0.7 \%)$ were excluded due to lack of details on the music genre played (Figure 2).

\section{Professional musicians sorted by music genre}

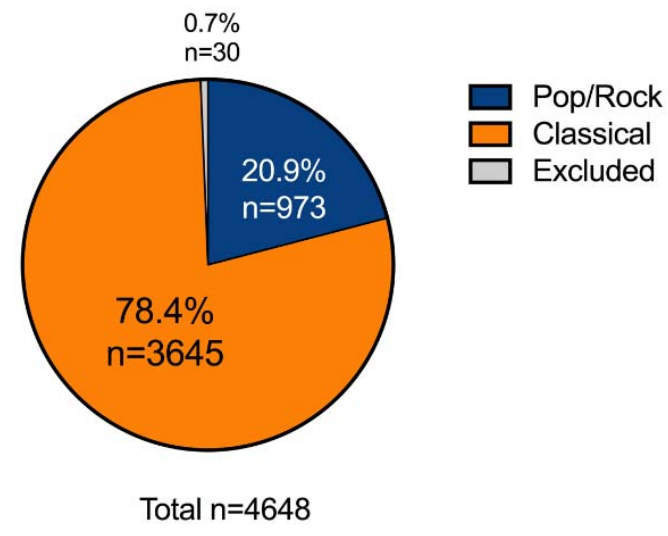

Figure 2. Distribution of professional musicians included in the review, divided by music genre (Pop/Rock; Classical).

Age for PR and CL PMs ranged from 16 to 69 years, with no significant differences between the groups ( $p=0.78) ; 2914(63.1 \%)$ of PMs included in the review were males; $1704(36.9 \%)$ were females.

\subsection{Hearing Loss and Audiological Symptoms}

HL (Pure tone threshold $>25 \mathrm{~dB}$ at any frequency in the $250-8000 \mathrm{~Hz}$ range) was investigated in $41 / 42(97.6 \%)$ articles included in the review (4507 PMs) and was found in 1742 subjects $(38.6 \%)$. PR PMs were more affected compared to CL PMs, with respectively 547/862 (63.5\%) and 1195/3645 (32.8\%) subjects; the odds ratio for PR was 1.3991 (CI 95\%: 0.4044-0.5441). The difference was statistically significant $(\chi: p<0.0001)$.

$\mathrm{HL}$ affected prevalently the high frequencies in the range between 3000 and $6000 \mathrm{~Hz}$. Among PR PMs, HL was reported for the $2000 \mathrm{~Hz}$ frequency in $16(2.9 \%)$ subjects, $3000 \mathrm{~Hz}$ in $352(64.3 \%), 4000 \mathrm{~Hz}$ in $370(68.2 \%), 6000 \mathrm{~Hz}$ in 493 (90.1\%), and $8000 \mathrm{~Hz}$ in $138 \mathrm{PMs}(25.2 \%)$. In CL PMs, HL affected the 250 $\mathrm{Hz}$ frequency in $42(3.5 \%)$ subjects, $500 \mathrm{~Hz}$ in $42(3.5 \%), 2000 \mathrm{~Hz}$ in $74(6.2 \%), 3000 \mathrm{~Hz}$ in $470(39.3 \%)$, $4000 \mathrm{~Hz}$ in $712(59.6 \%), 6000 \mathrm{~Hz}$ in $964(80.7 \%)$, and $8000 \mathrm{~Hz}$ in $454 \mathrm{PMs}(38 \%)$. Interestingly, no HL was reported for frequencies $<2000 \mathrm{~Hz}$ for PR PMs. Details of HL in PMs are shown in Figure 3.

HL was symmetric (thresholds for each ear within $15 \mathrm{~dB}$ of each other) in $835 \mathrm{PMs}$ and asymmetric in 772 PMs. Characteristics on HL symmetry were not reported for 135 (7.7\%) subjects (37 PR and 98 CL PMs). Symmetric HL was described in 347/510 (68\%) PR PMs and in 488/1097 (44.5\%) CL PMs; asymmetric hearing loss was present in 163 (32\%) PR and in 609 (55.9\%) CL PMs. CL PMs showed an odds ratio for asymmetric HL of 4.02 (CI 95\%: 3.2574-4.9823). The difference between PR and CL PMs for asymmetric hearing loss was statistically significant $(\chi: p<0.0001)$. Figure 4 shows the percentage of symmetric and asymmetric HL in PMs. 


\section{Affected frequencies among professional musicians with hearing loss}

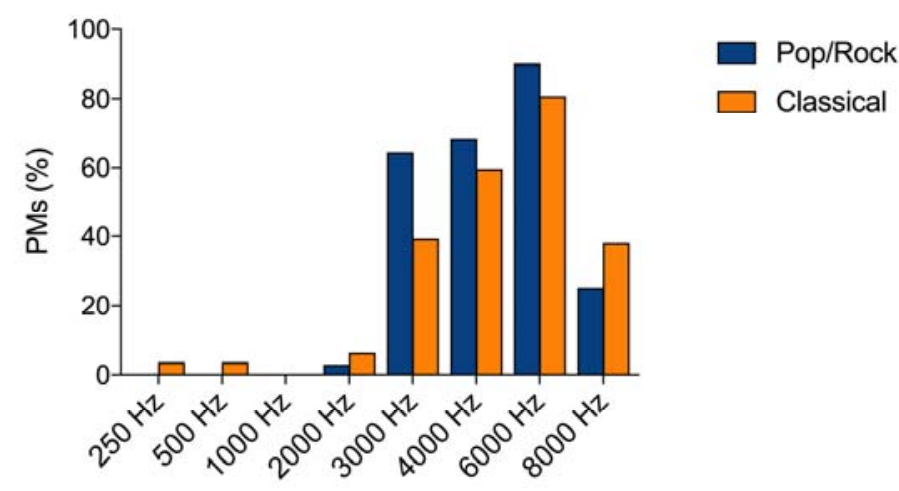

Figure 3. Affected frequencies among Pop/Rock and Classical professional musicians (PMs) with hearing loss included in the systematic review in the $250-8000 \mathrm{~Hz}$ frequency range. The most affected frequencies in both groups were 3000, 4000, and $6000 \mathrm{~Hz}$.

\section{Symmetric vs asymmetric hearing loss in professional musicians}

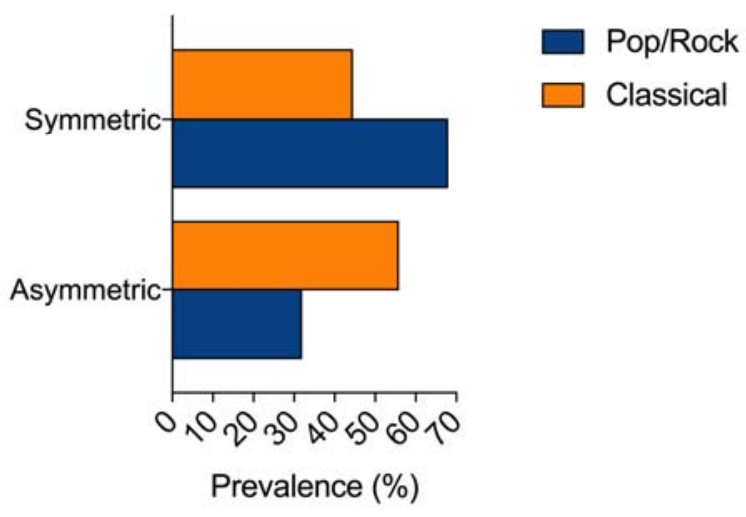

Figure 4. Percentage of symmetric and asymmetric hearing loss found in professional musicians (PMs) included in the systematic review. Symmetric HL was more common in Pop/Rock PMs, while asymmetric HL was more prevalent in Classical PMs. Data on symmetry were unavailable for 135 subjects.

The most common instruments were double bass, brass, flute, trumpet, percussion, strings, electric guitar, and piano. Although some are more commonly used by PR or CL PMs, in many cases they were used simultaneously in both genres. The highest extent of hearing loss was reported in PMs using strings $(n=1628)$, followed by percussion $(n=1050)$, brass $(n=775)$, double bass $(n=543)$, electric guitar $(n=424)$, piano $(n=314)$, flute $(n=341)$, and trumpet $(n=284)$. Details of affected frequencies in PMs sorted by instrument played are shown in Figure 5.

Tinnitus was investigated in 17/41 (41.5\%) studies including 2327 PMs (760 PR, 1567 CL) and was reported in 612 subjects (26.3\%). Of those, tinnitus was found in 196/760 (25.8\%) PR and in 416/1567 (26.5\%) CL PMs. The odds ratio was 0.98 (CI 95\%: 0.7616-1.131). No statistically significant difference was observed for tinnitus prevalence between CL and PR PMs $(\chi: p=0.45)$.

Hyperacusis was evaluated in 8/41 studies (19.5\%) including 791 PMs (288 PR, 503 CL) and was found in 172 musicians (21.7\%). Of these, 77/288 (26.7\%) were PR and 95/503 (18.9\%) were CL PMs. The odds ratio was 1.56 (CI 95\%: 1.1117-2.2095); the difference in the prevalence of hyperacusis between CL and PR was statistically significant $(\chi: p=0.01)$ with increased risk for PR PMs.

Diplacusis was investigated in only 2 studies (4.5\%) including 380 PMs and was found in 24 of them (6.3\%), specifically in 4/139 (2.9\%) PR and in 19/241 (7.9\%) of CL PMs. 
Tinnitus was equally prevalent in PR and CL PMs, while hyperacusis was more common in PR PMs and diplacusis in CL PMs. Figure 6 summarizes the prevalence of hearing loss, tinnitus, hyperacusis, and diplacusis in PR and CL PMs.

\section{Hearing loss in professional musicians sorted by instrument}

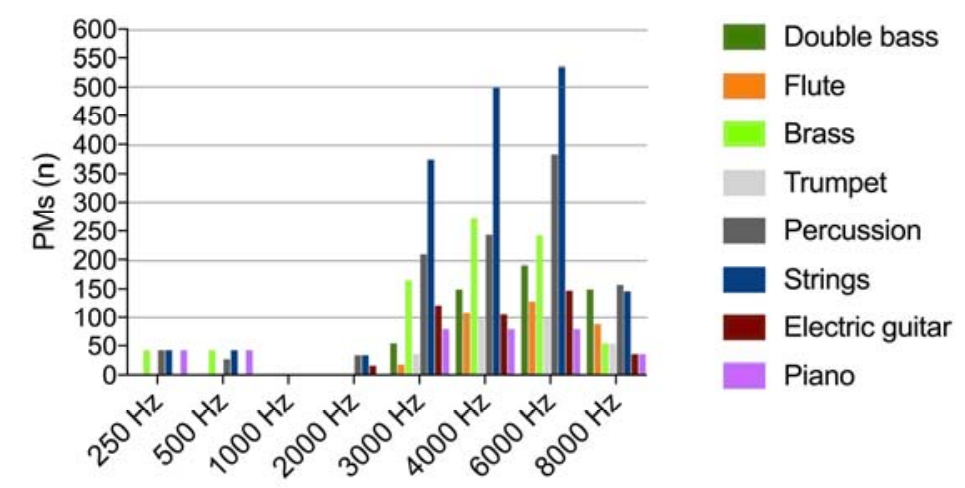

Figure 5. Number of professional musicians (PMs) with hearing loss in the 250-8000 Hz frequency range sorted by instrument played.

\section{Prevalence of hearing loss and associated symptoms in professional musicians}

Hearing Loss (41 studies, $n=4507)$

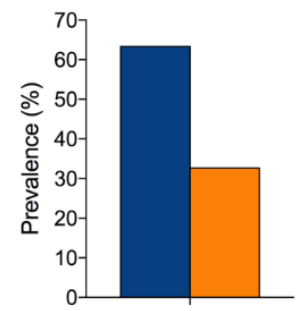

Hyperacusis ( 8 studies, $n=791$ )

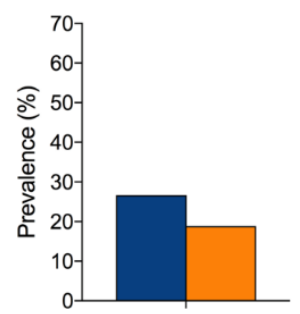

Tinnitus (17 studies, $\mathrm{n}=\mathbf{2 3 2 7}$ )

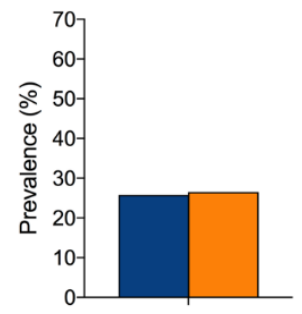

Diplacusis (2 studies, $\mathrm{n}=\mathbf{3 8 0}$ )

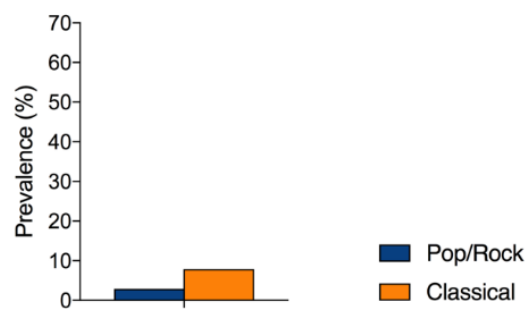

Figure 6. Prevalence of hearing loss tinnitus, hyperacusis, and diplacusis in Classical and Pop/Rock professional musicians included in the meta-analysis. For each condition, it has been indicated the number of studies that investigated it and the total number of patients included in these studies.

\section{Discussion}

Our systematic review of the literature showed that (A) 38.6\% of PMs have some degree of HL; (B) PR PMs are at higher risk of developing HL than CL PMs; (C) the most affected frequencies in PMs are in the 3000-6000 Hz range; (D) CL PMs suffer from asymmetric HL significantly more than PR PMs; and (E) tinnitus was equally prevalent in PR and CL PMs, hyperacusis was more common in PR PMs and diplacusis in CL PMs. 


\subsection{Risk of Developing Hearing Loss Among PR and CL PMs}

Our data shows that HL is common in PMs (38.6\%), and PR PMs are at higher risk of developing HL compared to CL PMs. The presence of HL in PMs is a common finding and follows prolonged and high-intensity noise exposure, a condition that causes a progressive reactive oxygen and nitrogen species-mediated destruction of inner and outer hair cells in the cochlea following oxidative stress, metabolic exhaustion, and ischemia [3-5]. In the studies included in our review, HL affected mainly frequencies in the $3000-6000 \mathrm{~Hz}$ range, with no significant differences between PR and CL musicians.

The higher prevalence of HL in PR compared to CL PMs can be explained by different characteristics of the music genre, such as frequency and intensity of the instruments used, differences in habits of PMs and in environmental acoustic settings. Instruments produce sounds that span between different frequency ranges and emit sounds at different intensities. The frequencies generated by the instruments played is a key factor when assessing the risk of developing HL for PMs [27]; therefore, the musical genre may affect the characteristics of sounds PMs are exposed during practice [27]. Previous studies have shown that PR PMs are exposed to sounds of higher intensity compared to CL PMs, both during rehearsals and live performance [31], with an average exposure of $103 \mathrm{~dB}$ in PR versus $94 \mathrm{~dB}$ in CL PMs [27]; additionally, studies have described that PR PMs often play music without ear protection more commonly than CL PMs $[28,29]$.

Furthermore, the introduction of new instruments such as the violin in PR music also plays a role, as the combination of high frequency-generating instruments and high intensity sound has been shown to increase risk of HL $[27,70]$.

Future research should focus on evaluating the effects of sound in the central auditory pathways. In fact, although the role of peripheral damage in HL has been widely studied, recent research findings support the idea that noise can induce hearing loss also by acting directly on the central auditory pathways [71,72].

\subsection{Characteristics of Hearing Loss Among PM}

Our systematic review shows that CL PMs suffer from asymmetric HL significantly more than PR PMs. This difference can be explained by the instruments played by these professionals: in a classical music orchestra, a large portion of musicians play single-sided instruments, such as the violin (string) or the transverse flute; with these instruments the ear that is on the ipsilateral side (commonly the left for right handed musicians) is the most exposed to sound [65]. In PR PMs, the low incidence of asymmetric HL could be explained by prolonged exposure to high intensity sounds, such as those generated by electronic guitars, and the Larsen effect. Furthermore, the instruments commonly played by PR musicians (guitar, bass, drum) are symmetric and tend to equally expose both ears to sound.

\subsection{Audiological Symptoms: Tinnitus, Hyperacusis, and Diplacusis}

Our review shows a prevalence of tinnitus of $26.3 \%$ in PMs in the studies that investigated the symptom; it was almost equally distributed between CL and PR PMs. Tinnitus may follow audiological, somatic, or psychological conditions [13,73-80]; risk factors for tinnitus include HL and increasing age $[15,16,81]$. The elevate prevalence of HL found in PMs can explain the presence of tinnitus in these patients; however, there was no higher prevalence of tinnitus among PR PMs compared to CL PRs. This could be explained by the different number of studies that were considered to evaluate the prevalence of HL $(n=41)$ and tinnitus $(n=17)$; unfortunately, many studies did not evaluate the presence of tinnitus.

Hyperacusis [21] was the second most common symptom found in our review, and was more common in PR PMs compared to CL PMs. Hyperacusis may follow functional changes within the central nervous system and may be related to increased gain in the central auditory pathways and increased anxiety, mood disorders, or emotional response to sound $[82,83]$. The higher prevalence of hyperacusis in PR PMs could be related to changes in mood that can be elicited by the different music 
genres and the different stress levels. In fact, the volume of music can influence not only mood but also stress level [84]. Subjects who listen to soft music commonly report an improvement in mood and a pleasure sensation with increased levels of serotonin and decreased cortisol levels [85]; conversely, high intensity and short sounds are associated with an increase in noradrenaline that stimulates hyper mood activity [86].

Although rare, diplacusis was observed in both PR and CL PMs, although it was more common among CL PMs. Diplacusis is a perceptual anomaly whereby the same sound is perceived as having a different pitch depending on whether it is presented in the left or the right ear; this phenomenon is common in individuals with asymmetric hearing loss [25]. The symptom can be due to a shift of the excitation peak from a high to a more basal region of the basilar membrane following a cochlear damage [87] which in turn causes a shift in the peak of the neural tuning curves of the auditory neurons toward lower frequencies [88] or to the fall of a specific frequency inside a dead cochlear region that evokes an unclear stimulus [89]. The limited number of studies that investigated this symptom included in this review does not allow a statistical analysis and comparison to other symptoms, but only the description of the phenomenon.

\subsection{Limits of Our Study}

Our study has some limits. First, the studies included in the review had a high degree of heterogeneity, especially for methodologies, evaluation of HL prior to exposure to music and outcome reporting. Secondly, we considered HL as any pure tone threshold higher than $25 \mathrm{~dB}$; however, definitions of $\mathrm{HL}$ in the included studies were not consistent. Furthermore, many studies did not report the entity of HL; therefore, in our study we could not describe the entity of HL and could only consider it as present/absent and symmetric/asymmetric. Associated symptoms have not been investigated in all the studies included in the review; therefore, the prevalence of the symptom could only be calculated for the studies that investigated it. Heterogeneity between studies also affected, even if at a lesser extent, the definitions of tinnitus, diplacusis, and hyperacusis. Taken together, these limits prevent the execution of a meta-analysis and should be considered when interpreting the results and the conclusions of our review.

\subsection{Future Perspectives for Early Diagnosis of Hearing Damage in Professional Musicians}

The use of individual hearing protection devices and strict regulations for time and entity of noise exposure is of paramount importance for the prevention of HL and associated symptoms in PMs. Future perspectives in noise-induced HL risk prevention are centered on early diagnosis of hearing impairment in predisposed individuals. On this topic, some authors recently proposed the use of microRNAs for monitoring the hearing damage [90] because they allow to investigate the hearing pathways from periphery (34a, 29b, 76, 96 and 431) to central auditory area (miR $-9 / 9 *)$. MicroRNA are very sensible to the cells metabolic alterations and they are commonly used for monitoring the progression of several disease [91,92]; furthermore, they have shown a high sensitivity in the early identification of inner ear cellular damage [93] and could play a role in the early diagnosis of hearing damage in individuals that are at risk of HL.

\section{Conclusions}

Our systematic review showed that HL is common in PMs, and PR PMs are at higher risk of developing HL compared to CL PMs. These findings could be explained by the prolonged exposure to high-frequency and high-intensity sounds common in PMs, that more often occurs in PR PMs. The prevalence of asymmetric HL was significantly higher in CL PMs compared to PR PMs, probably due to the type of instruments used. Tinnitus was equally present in PR and CL PMs; hyperacusis was more prevalent in PR PMs and diplacusis was more common in CL PMs. The use of individual hearing protection devices may help reduce the risk of noise-induced HL and associated symptoms in PMs; furthermore, the monitoring of microRNAs concentration associated with traditional hearing 
tests might play a role in the early diagnosis of hearing damage in exposed individuals that are at risk of HL.

Author Contributions: A.D.S. were the main investigators and contributed to the design and writing of the paper, L.D. contributed to writing paper and critically reviewed the paper, M.R. contributed to the design of the paper, A.D.V. performed the review of the literature, A.M. and A.G. supervised the work and provided experimental insights, G.R. and M.d.V. critically reviewed the paper and contributed to its final edition.

Funding: The authors have not received financial support for this research and work.

Conflicts of Interest: The authors declare no conflict of interest.

\section{References}

1. Nelson, D.I.; Nelson, R.Y.; Concha-Barrientos, M.; Fingerhut, M. The global burden of occupational noise-induced hearing loss. Am. J. Ind. Med. 2005, 48, 446-458. [CrossRef] [PubMed]

2. Tikka, C.; Verbeek, J.H.; Kateman, E.; Morata, T.C.; Dreschler, W.A.; Ferrite, S. Interventions to prevent occupational noise-induced hearing loss. Cochrane Database Syst. Rev. 2017, 7, CD006396. [CrossRef] [PubMed]

3. Henderson, D.; Bielefeld, E.C.; Harris, K.C.; Hu, B.H. The role of oxidative stress in noise-induced hearing loss. Ear Hear. 2006, 27, 1-19. [CrossRef] [PubMed]

4. Fetoni, A.R.; Ralli, M.; Sergi, B.; Parrilla, C.; Troiani, D.; Paludetti, G. Protective properties of antioxidant drugs in noise-induced hearing loss in the guinea pig. Audiol. Med. 2009, 6, 271-277. [CrossRef]

5. Fetoni, A.R.; Garzaro, M.; Ralli, M.; Landolfo, V.; Sensini, M.; Pecorari, G.; Mordente, A.; Paludetti, G.; Giordano, $\mathrm{C}$. The monitoring role of otoacoustic emissions and oxidative stress markers in the protective effects of antioxidant administration in noise-exposed subjects: A pilot study. Med. Sci. Monit. 2009, 15, PR1-PR8.

6. Sliwinska-Kowalska, M.; Zaborowski, K. WHO Environmental Noise Guidelines for the European Region: A Systematic Review on Environmental Noise and Permanent Hearing Loss and Tinnitus. Int. J. Environ. Res. Public Health 2017, 14. [CrossRef] [PubMed]

7. Masterson, E.A.; Bushnell, P.T.; Themann, C.L.; Morata, T.C. Hearing Impairment Among Noise-Exposed Workers-United States, 2003-2012. MMWR Morb. Mortal. Wkly. Rep. 2016, 65, 389-394. [CrossRef] [PubMed]

8. Masterson, E.A.; Tak, S.; Themann, C.L.; Wall, D.K.; Groenewold, M.R.; Deddens, J.A.; Calvert, G.M. Prevalence of hearing loss in the United States by industry. Am. J. Ind. Med. 2013, 56, 670-681. [CrossRef] [PubMed]

9. Ivory, R.; Kane, R.; Diaz, R.C. Noise-induced hearing loss: A recreational noise perspective. Curr. Opin. Otolaryngol. Head Neck Surg. 2014, 22, 394-398. [CrossRef] [PubMed]

10. Katbamna, B.; Flamme, G.A. Acquired hearing loss in adolescents. Pediatr. Clin. N. Am. 2008, 55, 1391-1402. [CrossRef] [PubMed]

11. Seidman, M.D.; Standring, R.T. Noise and quality of life. Int. J. Environ. Res. Public Health 2010, 7, 3730-3738. [CrossRef] [PubMed]

12. Lie, A.; Skogstad, M.; Johannessen, H.A.; Tynes, T.; Mehlum, I.S.; Nordby, K.C.; Engdahl, B.; Tambs, K. Occupational noise exposure and hearing: A systematic review. Int. Arch. Occup. Environ. Health 2016, 89, 351-372. [CrossRef] [PubMed]

13. Baguley, D.; McFerran, D.; Hall, D. Tinnitus. Lancet 2013, 382, 1600-1607. [CrossRef]

14. Langguth, B.; Kreuzer, P.M.; Kleinjung, T.; De Ridder, D. Tinnitus: Causes and clinical management. Lancet Neurol. 2013, 12, 920-930. [CrossRef]

15. Shargorodsky, J.; Curhan, G.C.; Farwell, W.R. Prevalence and characteristics of tinnitus among US adults. Am. J. Med. 2010, 123, 711-718. [CrossRef] [PubMed]

16. Davis, A.; Smith, P.A.; Booth, M.; Martin, M. Diagnosing Patients with Age-Related Hearing Loss and Tinnitus: Supporting GP Clinical Engagement through Innovation and Pathway Redesign in Audiology Services. Int. J. Otolaryngol. 2012, 2012, 290291. [CrossRef] [PubMed]

17. Mrena, R.; Savolainen, S.; Kuokkanen, J.T.; Ylikoski, J. Characteristics of tinnitus induced by acute acoustic trauma: A long-term follow-up. Audiol. Neurootol. 2002, 7, 122-130. [CrossRef] [PubMed] 
18. Nageris, B.I.; Attias, J.; Raveh, E. Test-retest tinnitus characteristics in patients with noise-induced hearing loss. Am. J. Otolaryngol. 2010, 31, 181-184. [CrossRef] [PubMed]

19. Ricci, S.; Massoni, F.; Di Meo, M.; Petrone, L.; Canitano, N.; Ippoliti, F.; Cinti, M.E. Correlation among measures of stress, indicators of biohumoral nature and medico-legal considerations. Riv. Psichiatr. 2013, 48, 113-120. [CrossRef] [PubMed]

20. Ralli, M.; Balla, M.P.; Greco, A.; Altissimi, G.; Ricci, P.; Turchetta, R.; Virgilio, A.; Vincentiis, M.; Ricci, S.; Cianfrone, G. Work-Related Noise Exposure in a Cohort of Patients with Chronic Tinnitus: Analysis of Demographic and Audiological Characteristics. Int. J. Environ. Res. Public Health 2017, 14. [CrossRef] [PubMed]

21. Aazh, H.; McFerran, D.; Salvi, R.; Prasher, D.; Jastreboff, M.; Jastreboff, P. Insights from the First International Conference on Hyperacusis: Causes, evaluation, diagnosis and treatment. Noise Health 2014, 16, 123-126. [CrossRef] [PubMed]

22. Heller, A.J. Classification and epidemiology of tinnitus. Otolaryngol. Clin. N. Am. 2003, 36, $239-248$. [CrossRef]

23. Erlandsson, S.I.; Hallberg, L.R.; Axelsson, A. Psychological and audiological correlates of perceived tinnitus severity. Audiology 1992, 31, 168-179. [CrossRef] [PubMed]

24. Reiss, L.A.; Shayman, C.S.; Walker, E.P.; Bennett, K.O.; Fowler, J.R.; Hartling, C.L.; Glickman, B.; Lasarev, M.R.; Oh, Y. Binaural pitch fusion: Comparison of normal-hearing and hearing-impaired listeners. J. Acoust. Soc. Am. 2017, 141, 1909-1920. [CrossRef] [PubMed]

25. Colin, D.; Micheyl, C.; Girod, A.; Truy, E.; Gallego, S. Binaural Diplacusis and Its Relationship with Hearing-Threshold Asymmetry. PLoS ONE 2016, 11, e0159975. [CrossRef] [PubMed]

26. Clark, W.W. Noise exposure from leisure activities: A review. J. Acoust. Soc. Am. 1991, 90, 175-181. [CrossRef] [PubMed]

27. Di Stadio, A. Which factors to induce hearing loss in professional musicians? Extensive literature review and histopathology findings can answer it. Hear. Balance Commun. 2017, 15, 63-71. [CrossRef]

28. Hoydal, E.H.; Lein Stormer, C.C.; Laukli, E.; Stenklev, N.C. Transient evoked otoacoustic emissions in rock musicians. Int. J. Audiol. 2017, 56, 685-691. [CrossRef] [PubMed]

29. Mendes, M.H.; Morata, T.C.; Marques, J.M. Acceptance of hearing protection aids in members of an instrumental and voice music band. Braz. J. Otorhinolaryngol. 2007, 73, 785-792. [CrossRef]

30. Eaton, S.; Gillis, H. Review of orchestra musicians' hearing loss risks. Can. Acoust. 2002, 2, 5-12.

31. Halevi-Katz, D.N.; Yaakobi, E.; Putter-Katz, H. Exposure to music and noise-induced hearing loss (NIHL) among professional pop/rock/jazz musicians. Noise Health 2015, 17, 158-164. [CrossRef] [PubMed]

32. Moher, D.; Liberati, A.; Tetzlaff, J.; Altman, D.G.; Group, P. Preferred reporting items for systematic reviews and meta-analyses: The PRISMA statement. PLoS Med. 2009, 6, e1000097. [CrossRef] [PubMed]

33. Axelsson, A.; Lindgren, F. Hearing in pop musicians. Acta Otolaryngol. 1978, 85, 225-231. [CrossRef] [PubMed]

34. Axelsson, A.; Lindgren, F. Hearing in classical musicians. Acta Otolaryngol. Suppl. 1981, 377, 3-74. [CrossRef] [PubMed]

35. Axelsson, A.; Lindgren, F. Pop music and hearing. Ear Hear. 1981, 2, 64-69. [CrossRef] [PubMed]

36. Karlsson, K.; Lundquist, P.G.; Olaussen, T. The hearing of symphony orchestra musicians. Scand. Audiol. 1983, 12, 257-264. [CrossRef] [PubMed]

37. Johnson, D.W.; Sherman, R.E.; Aldridge, J.; Lorraine, A. Extended high frequency hearing sensitivity. A normative threshold study in musicians. Ann. Otol. Rhinol. Laryngol. 1986, 95, 196-202. [CrossRef] [PubMed]

38. Royster, J.D.; Royster, L.H.; Killion, M.C. Sound exposures and hearing thresholds of symphony orchestra musicians. J. Acoust. Soc. Am. 1991, 89, 2793-2803. [CrossRef] [PubMed]

39. Axelsson, A.; Eliasson, A.; Israelsson, B. Hearing in pop/rock musicians: A follow-up study. Ear Hear. 1995, 16, 245-253. [CrossRef] [PubMed]

40. Obeling, L.; Poulsen, T. Hearing ability in Danish symphony orchestra musicians. Noise Health 1999, 1, 43-49. [PubMed]

41. Kahari, K.R.; Axelsson, A.; Hellstrom, P.A.; Zachau, G. Hearing development in classical orchestral musicians. A follow-up study. Scand. Audiol. 2001, 30, 141-149. [CrossRef] [PubMed]

42. Kahari, K.R.; Axelsson, A.; Hellstrom, P.A.; Zachau, G. Hearing assessment of classical orchestral musicians. Scand. Audiol. 2001, 30, 13-23. [CrossRef] [PubMed] 
43. Kaharit, K.; Zachau, G.; Eklof, M.; Sandsjo, L.; Moller, C. Assessment of hearing and hearing disorders in rock/jazz musicians. Int. J. Audiol. 2003, 42, 279-288. [CrossRef] [PubMed]

44. Amorim, R.B.; Lopes, A.C.; Santos, K.T.P.; Melo, A.D.P.; Lauris, J.R.P. Auditory alterations for Occupational exposition in musician. Int. Arch. Otorhinolaryngol. 2008, 3, 377-383.

45. Sayegh Ghoussoub, M.; Ghoussoub, K.; Chaaya, A.; Sleilaty, G.; Joubrel, I.; Rifai, K. Orofacial and hearing specific problems among 340 wind instrumentalists in Lebanon. J. Med. Liban. 2008, 56, 159-167. [PubMed]

46. Jansen, E.J.; Helleman, H.W.; Dreschler, W.A.; de Laat, J.A. Noise induced hearing loss and other hearing complaints among musicians of symphony orchestras. Int. Arch. Occup. Environ. Health 2009, 82, 153-164. [CrossRef] [PubMed]

47. Hasson, D.; Theorell, T.; Liljeholm-Johansson, Y.; Canlon, B. Psychosocial and physiological correlates of self-reported hearing problems in male and female musicians in symphony orchestras. Int. J. Psychophysiol. 2009, 74, 93-100. [CrossRef] [PubMed]

48. Phillips, S.L.; Henrich, V.C.; Mace, S.T. Prevalence of noise-induced hearing loss in student musicians. Int. J. Audiol. 2010, 49, 309-316. [CrossRef] [PubMed]

49. Pawlaczyk-Luszczynska, M.; Dudarewicz, A.; Zamojska, M.; Sliwinska-Kowalska, M. Evaluation of sound exposure and risk of hearing impairment in orchestral musicians. Int. J. Occup. Saf. Ergon. 2011, 17, 255-269. [CrossRef] [PubMed]

50. Toppila, E.; Koskinen, H.; Pyykko, I. Hearing loss among classical-orchestra musicians. Noise Health 2011, 13, 45-50. [CrossRef] [PubMed]

51. Samelli, A.G.; Matas, C.G.; Carvallo, R.M.; Gomes, R.F.; de Beija, C.S.; Magliaro, F.C.; Rabelo, C.M. Audiological and electrophysiological assessment of professional pop/rock musicians. Noise Health 2012, 14, 6-12. [CrossRef] [PubMed]

52. Raymond, D.M., 3rd; Romeo, J.H.; Kumke, K.V. A pilot study of occupational injury and illness experienced by classical musicians. Workplace Health Saf. 2012, 60, 19-24. [CrossRef] [PubMed]

53. Russo, F.A.; Behar, A.; Chasin, M.; Mosher, S. Hearing loss in British Army musicians. Occup. Med. 2013, 63, 281-283. [CrossRef]

54. Russo, F.A.; Behar, A.; Chasin, M.; Mosher, S. Noise exposure and hearing loss in classical orchestra musicians. Int. J. Ind. Ergon. 2013, 43, 474-478. [CrossRef]

55. Goncalves, C.G.; Lacerda, A.B.; Zeigelboim, B.S.; Marques, J.M.; Luders, D. Auditory thresholds among military musicians: Conventional and high frequency. Codas 2013, 25, 181-187. [PubMed]

56. Wilson, W.J.; O'Brien, I.; Bradley, A.P. The audiological health of horn players. J. Occup. Environ. Hyg. 2013, 10, 590-596. [CrossRef] [PubMed]

57. Luders, D.; Goncalves, C.G.; Lacerda, A.B.; Ribas, A.; Conto, J. Music students: Conventional hearing thresholds and at high frequencies. Braz. J. Otorhinolaryngol. 2014, 80, 296-304. [CrossRef] [PubMed]

58. O'Brien, I.; Ackermann, B.J.; Driscoll, T. Hearing and hearing conservation practices among Australia's professional orchestral musicians. Noise Health 2014, 16, 189-195. [CrossRef] [PubMed]

59. Schmidt, J.H.; Pedersen, E.R.; Paarup, H.M.; Christensen-Dalsgaard, J.; Andersen, T.; Poulsen, T.; Baelum, J. Hearing loss in relation to sound exposure of professional symphony orchestra musicians. Ear Hear. 2014, 35, 448-460. [CrossRef] [PubMed]

60. Dudarewicz, A.; Pawlaczyk-Luszczynska, M.; Zamojska-Daniszewska, M.; Zaborowski, K. Exposure to excessive sounds during orchestra rehearsals and temporary hearing changes in hearing among musicians. Med. Pr. 2015, 66, 479-486. [CrossRef] [PubMed]

61. Stormer, C.C.; Laukli, E.; Hoydal, E.H.; Stenklev, N.C. Hearing loss and tinnitus in rock musicians: A Norwegian survey. Noise Health 2015, 17, 411-421. [CrossRef] [PubMed]

62. Luders, D.; Goncalves, C.G.; Lacerda, A.B.; Silva, L.S.; Marques, J.M.; Sperotto, V.N. Occurrence of tinnitus and other auditory symptoms among musicians playing different instruments. Int. Tinnitus J. 2016, 20, 48-53. [CrossRef] [PubMed]

63. Henning, R.L.; Bobholz, K. Distortion product otoacoustic emissions in college music majors and nonmusic majors. Noise Health 2016, 18, 10-20. [CrossRef] [PubMed]

64. Lüders, D.; Gonçalves, C.G.D.O.; Lacerda, A.B.M.D.; Schettini, S.R.L.; Silva, L.S.G.D.; Albizu, E.J.; Marques, J.M. Hearing and quality of life in musicians of a symphony orchestra. Audiol. Commun. Res. 2016, 21, 1688. 
65. Pouryaghoub, G.; Mehrdad, R.; Pourhosein, S. Noise-Induced hearing loss among professional musicians. J. Occup. Health 2017, 59, 33-37. [CrossRef] [PubMed]

66. Pawlaczyk-Luszczynska, M.; Zamojska-Daniszewska, M.; Dudarewicz, A.; Zaborowski, K. Exposure to excessive sounds and hearing status in academic classical music students. Int. J. Occup. Med. Environ. Health 2017, 30, 55-75. [CrossRef] [PubMed]

67. Stormer, C.C.L.; Sorlie, T.; Stenklev, N.C. Tinnitus, Anxiety, Depression and Substance Abuse in Rock Musicians a Norwegian Survey. Int. Tinnitus J. 2017, 21, 50-57. [CrossRef] [PubMed]

68. Szibor, A.; Hyvarinen, P.; Lehtimaki, J.; Pirvola, U.; Ylikoski, M.; Makitie, A.; Aarnisalo, A.; Ylikoski, J. Hearing disorder from music; a neglected dysfunction. Acta Otolaryngol. 2018, 138, 21-24. [CrossRef] [PubMed]

69. Behar, A.; Chasin, M.; Mosher, S.; Abdoli-Eramaki, M.; Russo, F.A. Noise exposure and hearing loss in classical orchestra musicians: A five-year follow-up. Noise Health 2018, 20, 42-46. [CrossRef] [PubMed]

70. da Silva, V.G.; de Oliveira, C.A.; Tauil, P.L.; de Castro Silva, I.M.; Sampaio, A.L. Amplified music exposure carries risks to hearing. Int. J. Pediatr. Otorhinolaryngol. 2017, 93, 117-122. [CrossRef] [PubMed]

71. Saljo, A.; Bao, F.; Hamberger, A.; Haglid, K.G.; Hansson, H.A. Exposure to short-lasting impulse noise causes microglial and astroglial cell activation in the adult rat brain. Pathophysiology 2001, 8, 105-111. [CrossRef]

72. Tarabichi, O.; Kozin, E.D.; Kanumuri, V.V.; Barber, S.; Ghosh, S.; Sitek, K.R.; Reinshagen, K.; Herrmann, B.; Remenschneider, A.K.; Lee, D.J. Diffusion Tensor Imaging of Central Auditory Pathways in Patients with Sensorineural Hearing Loss: A Systematic Review. Otolaryngol. Head Neck Surg. 2018, 158, 432-442. [CrossRef] [PubMed]

73. Ralli, M.; Altissimi, G.; Turchetta, R.; Mazzei, F.; Salviati, M.; Cianfrone, F.; Orlando, M.P.; Testugini, V.; Cianfrone, G. Somatosensory Tinnitus: Correlation between Cranio-Cervico-Mandibular Disorder History and Somatic Modulation. Audiol. Neurootol. 2016, 21, 372-382. [CrossRef] [PubMed]

74. Ralli, M.; Greco, A.; Turchetta, R.; Altissimi, G.; de Vincentiis, M.; Cianfrone, G. Somatosensory tinnitus: Current evidence and future perspectives. J. Int. Med. Res. 2017, 45, 933-947. [CrossRef] [PubMed]

75. Bhatt, J.M.; Lin, H.W.; Bhattacharyya, N. Prevalence, Severity, Exposures, and Treatment Patterns of Tinnitus in the United States. JAMA Otolaryngol. Head Neck Surg. 2016, 142, 959-965. [CrossRef] [PubMed]

76. Moller, A.R. Epidemiology of Tinnitus in Adults. In Textbook of Tinnitus; Springer: New York, NY, USA, 2011; pp. 29-37.

77. Moller, A.R.; Salvi, R.; De Ridder, D.; Kleinjung, T.; Vanneste, S. Pathology of Tinnitus and Hyperacusis-Clinical Implications. Biomed. Res. Int. 2015, 2015, 608437. [CrossRef] [PubMed]

78. Roberts, L.E.; Eggermont, J.J.; Caspary, D.M.; Shore, S.E.; Melcher, J.R.; Kaltenbach, J.A. Ringing ears: The neuroscience of tinnitus. J. Neurosci. 2010, 30, 14972-14979. [CrossRef] [PubMed]

79. Shore, S.; Zhou, J.; Koehler, S. Neural mechanisms underlying somatic tinnitus. Prog. Brain Res. 2007, 166, 107-123. [CrossRef] [PubMed]

80. Ralli, M.; Greco, A.; Boccassini, A.; Altissimi, G.; Di Paolo, C.; Falasca, V.; De Virgilio, A.; Polimeni, A.; Cianfrone, G.; de Vincentiis, M. Subtyping patients with somatic tinnitus: Modulation of tinnitus and history for somatic dysfunction help identify tinnitus patients with temporomandibular joint disorders. PLoS ONE 2018, 13, e0202050. [CrossRef] [PubMed]

81. Nondahl, D.M.; Cruickshanks, K.J.; Wiley, T.L.; Klein, R.; Klein, B.E.; Tweed, T.S. Prevalence and 5-year incidence of tinnitus among older adults: The epidemiology of hearing loss study. J. Am. Acad. Audiol. 2002, 13, 323-331. [PubMed]

82. Salvi, R.J.; Wang, J.; Ding, D. Auditory plasticity and hyperactivity following cochlear damage. Hear. Res. 2000, 147, 261-274. [CrossRef]

83. Baguley, D.M. Hyperacusis. J. R. Soc. Med. 2003, 96, 582-585. [CrossRef] [PubMed]

84. Staum, M.J.; Brotons, M. The effect of music amplitude on the relaxation response. J. Music Ther. 2000, 37, 22-39. [CrossRef] [PubMed]

85. Chanda, M.L.; Levitin, D.J. The neurochemistry of music. Trends Cogn. Sci. 2013, 17, 179-193. [CrossRef] [PubMed]

86. Mockel, M.; Rocker, L.; Stork, T.; Vollert, J.; Danne, O.; Eichstadt, H.; Muller, R.; Hochrein, H. Immediate physiological responses of healthy volunteers to different types of music: Cardiovascular, hormonal and mental changes. Eur. J. Appl. Physiol. Occup. Physiol. 1994, 68, 451-459. [CrossRef] [PubMed] 
87. Muller, M.; Hoidis, S.; Smolders, J.W. A physiological frequency-position map of the chinchilla cochlea. Hear. Res. 2010, 268, 184-193. [CrossRef] [PubMed]

88. Henry, K.S.; Kale, S.; Heinz, M.G. Distorted Tonotopic Coding of Temporal Envelope and Fine Structure with Noise-Induced Hearing Loss. J. Neurosci. 2016, 36, 2227-2237. [CrossRef] [PubMed]

89. Huss, M.; Moore, B.C. Dead regions and pitch perception. J. Acoust. Soc. Am. 2005, 117, 3841-3852. [CrossRef] [PubMed]

90. Di Stadio, A.; Pegoraro, V.; Giaretta, L.; Dipietro, L.; Marozzo, R.; Angelini, C. Hearing impairment in MELAS: New prospective in clinical use of microRNA, a systematic review. Orphanet J. Rare Dis. 2018, 13, 35. [CrossRef] [PubMed]

91. Fransquet, P.D.; Ryan, J. Micro RNA as a potential blood-based epigenetic biomarker for Alzheimer's disease. Clin. Biochem. 2018, 58, 5-14. [CrossRef] [PubMed]

92. Mansoori, B.; Mohammadi, A.; Shirjang, S.; Baradaran, B. Micro-RNAs: The new potential biomarkers in cancer diagnosis, prognosis and cancer therapy. Cell. Mol. Biol. 2015, 61, 1-10. [PubMed]

93. Patel, M.; Hu, B.H. MicroRNAs in inner ear biology and pathogenesis. Hear. Res. 2012, 287, 6-14. [CrossRef] [PubMed]

(C) 2018 by the authors. Licensee MDPI, Basel, Switzerland. This article is an open access article distributed under the terms and conditions of the Creative Commons Attribution (CC BY) license (http://creativecommons.org/licenses/by/4.0/). 